\section{Lembaran Sejarah}

\title{
Strategies of Rent Seeking during The Sukarno Period: Foreigners and Corruption, 1950-1965
}

\section{FARABI FAKIH}

Universitas Gadjah Mada

\begin{abstract}
This articles tries to analyze the corruption strategy that was becoming institutionalized during the Liberal Democracy (1950-1957) and Guided Democracy (1957-1965) period and how the state dealt with these challenges through managerial strategies. Corruption here is seen as a discourse that are often used by new state elite entrant to discredit old elites, especially those with connection to the financial or economic policy makers. The position of foreigners here are central because they provide opportunities for asset transfer or the creation of new assets. By looking at the financial transition from Liberal Democracy to Guided Democracy, the forms of transfer or asset production through corruption or collusion could be discerned.
\end{abstract}

\begin{abstract}
Abstrak
Artikel ini berusaha menguliti strategi korupsi yang mulai terpatri pada masa Demokrasi Liberal (1950-1957) dan Demokrasi Terpimpin (1957-1965) serta bagaimana negara menjawab tantangan tersebut lewat usaha-usaha manajerial. Korupsi disini dilihat sebagai wacana yang seringkali dipakai oleh entrant atau elit baru negara untuk mendiskreditkan elit-elit lama, khususnya mereka yang punya koneksi kepada kebijakan keuangan dan ekonomi. Posisi orang asing disini sangat sentral karena mereka menyediakan kesempatan untuk transfer aset ataupun penciptaan aset baru. Dengan melihat pada transisi kekuasaan dari Demokrasi Liberal kepada Demokrasi Terpimpin, bentuk-bentuk transfer ataupun produksi asset lewat praktek korupsi dan kolusi disini dijabarkan.
\end{abstract}

Keywords: corruption; managerial elite; legitimating discourses; asset transfer

Kata Kunci: korupsi; elit manajerial; wacana legitimasi; transfer aset 


\section{Introduction}

The article is a preliminary look at the ways we can tackle corruption in Indonesian history. In particular, it is a preliminary look into cases of corruption surrounding the Old Order period and its relationship with the foreign world. There is a tendency in Indonesia to believe that outside businesses, including foreign direct investments, have an unfair advantage in affecting policymaking. Although this image is usually directed against the 'pro-Western' New Order government, it is the belief of the author that large parts of the characteristic of the relationship were formed during the Old Order period, especially in connection with corruption. Another important image of foreign business was its corrupting tendency: that in order to get what it wants, foreign business was capable to manipulate Indonesian policymakers in order to obtain what it wants.

Few studies on Indonesia in the Old Order tackle the issue of corruption directly. Leslie Palmier has produced several articles on the problem (Palmier, 2006: 147-160, 1982: 3-12) and John Mackie discussed about the Commission of Four during the early New Order period (Mackie, 1970: 87-101). Harold Crouch and Richard Robison saw corruption as part of wider political phenomenon, i.e. patrimonialism (Robison, 2009: 391395; Crouch, 1979: 571-587; Mackie, in: Aspinall and Fealy [eds], 2010). Yet, Indonesian talked about corruption incessantly since independence. How Indonesian thought about corruption informed them both of the limitation of their political and social system, but also the types of activities that could be conducted. Within the nascent managerial class, managers talked about the colonial period as one in which people conducted their business without corrupt practices $^{1}$ (Noermattias, 1973: 76; Sutomo, 1952). The managers saw the problem of corruption as a problem of lack of coordination and misadministration, to be remedied through the imposition of a managerially and organizationally modern state. Yet, the New Order state that arose was as corrupt as the Old Order; it behooves us to look into the Old Order and the problems of the corrupt Indonesian state.

By looking into case studies, this paper wants to look into the forms of corruption in Indonesian history and its relationship with foreigners during. Geoffrey Hodgson and Shuxia Jiang point out that while corruption is trendy

1) Noermattias, the head of the Indonesian Efficiency Institute (Formerly Indonesia Training Within Industry) said: "In (the colonial period) corruption within the Post and Telegraph Office did not exist." This belief was widespread amongst post-colonial Indonesian bureaucracy out of either truth or nostalgia. This nostalgia for the zaman normal, pre-corrupt days was a theme amongst many people, even those that resented the Dutch. Sutomo interviewed various Indonesian leaders in the early 1950s in order to get a picture of the problem with Indonesian management and its corrupt practices. He came to the conclusion that the only way in which Indonesian administrators could be freed from corrupt practices is to mimic the esprit de corps of the Dutch colonial administrators through its institutions like the soos. 
amongst social scientists, "much less attention so far, has been devoted to the concept of corruption, its meaning, and its definition" (Hodgson \& Jiang, 2007: 1043-1061). By collating cases of past corruption, how society reacts within that historical context and analyzing the discourse surrounding corruption, a better understanding of Indonesian corruption practices could emerge. Conducting analyses of Indonesian economic growth (and its failure) should understand the roots of its institutional forms and in this case the various forms of rent-seeking forms that developed in the past.

\section{Corruption and Business during the Parliamentary Period}

Corruption was often times pictured as a problem that arose as a result of the relationship between 'foreigners' and Indonesian. Thus, corruption occurred at the interstices when an Indonesian aligns with foreign interests. For instance, the failure of the Benteng Programme was pictured not only as a result of the corrupt practices of the Indonesian businessmen but also their relationship with Chinese-Indonesian or the Ali-Baba business model (Lindblad, 2008: 125-136; Wie, in: Lindblad and Post (eds.), 2009: 32-33). During the revolutionary period, corruption within the Dutch controlled territories had become a liability to the image of the Dutch as an honest and capable administrator, an image that was the bedrock of the Dutch claim to legitimacy as ruler in the archipelago. One of the most damning was a letter by the Auditor General of the Military to the Governor General saying that "corruption was widespread over a broad military and civilian front". Discussions in The Hague point the culprit to Eastern Culture.

According to the auditor general, the problem lay in the difference between the pay scale of regular civil servants and those working in the trading offices or other private companies. Corruption in 1948 was thus mostly found in those occupying semi-official agencies whose duty resulted in regular contacts with people working in these private sectors. These semiofficial positions were improvised offices accepting personnel without any rigorous selection process. Corruption in this period was limited to those newly-created temporary government services and not to the traditional administrative corps, in which most of the personnel came from the private business community.

\section{Parliamentary Efforts at Anti-Corruption}

After the transfer of sovereignty, corruption became a major part of the national discourse. The rise of the PNI-led Cabinet of Ali Sastroamidjojo represented a major shift in the management of the country, at least according to many observers. Feith recounted the end of the Wilopo Cabinet

2) ARA, 2.10.14.3285, Algemene Secretarie, Letter from Lieutenant-Colonel P. Kapteijn to the Luitenant Governor General, 22 March 1948. 
as an end of the rule of the social democrat since the Hatta Premiership in the late 1940s (Feith, 2009). The social democrats, especially the PSI, were considered to contain the bulk of the 'administrator' part of the Indonesian leadership. A couple of months into the Sastroamidjojo Cabinet, a pamphlet published by Masjumi purport to show the extensive nature of corruption under Ali Sastroamidjojo. In response to public criticism, Ali Sastroamidjojo appointed the NU Siradjuddin Abbas as Minister of General Welfare to eradicate corruption. ${ }^{3}$ The Ministry appointed a six-man committee. The committee was meant to investigate and categorize corruption cases and they found 59 types of corruptions. Minister Abbas said that corruption was on a much greater scale in the center than in the regions. The Ministry's draft anti-corruption law was finished by early June 1955.

By the time the first Ali Cabinet fell, Abbas's Anti-Corruption Law was not passed. The Burhanuddin Cabinet appointed an ad-hoc team in order to continue the work of the Ministry of State Welfare within the Ministry of Justice of Lukman Wiriadinata (Harahap, 1956: 29). The committee was headed by First Minister Djanu Ismail and had a broader scope of members than that of Abbas's committee, including the Minister of Finance, Economic Affairs, Justice and State Ministers Abdul Hakim and Supomo. The Ad Hoc Committee was supposed to have finished a draft by 9 September but had only met once on 1 September. According to Minister Lukman, Abbas's anti-corruption definitions were too broad and unclear (Tangkas, 6 September 1955). The new anti-corruption law would enforce all rich civil servants to account for their wealth and create a corruption court (Tangkas, 23 September 1955). By 30 September, the Ministerial Board has (Tangkas, 17 July 1955) approved of the creation of a special court and a bureau to investigate wealth. A special court would be created in Jakarta, Surabaya, Medan, and Makassar. In major corruption cases, a collegiate body of judges presides the case (Tangkas, 1 October 1955).

In cooperation with the Military Police (CPM), the Burhanuddin Cabinet conducted extra-legal arrests of high profile individual on corruption charges starting from late July 1955. By August, 16 formerly high ranking people of the government were arrested or under house arrest. Former ministers, including Minister of Justice Mr. Djody Gondokusuma and his secretary Subagio and Dr. Ong Eng Die, Minister of Finance of the Ali Sastroamidjojo Cabinet, were implicated. Mr. Muhammad Yamin, as Minister of Education and Culture of the Ali Sastroamidjojo, was under house arrest and a series of high officials in several government offices were implicated, both within the police, in the KPUI (Office on Import Affairs), LAAPLN (Bureau for Foreign Exchange) and the Bureau of Foreigners

3) Initially, anti-corruption was in the hands of the Ministry of State Welfare with Minister Sudibjo. Keterangan pemerintah atas program kabinet Ali Sastroamidjojo. 
(Tangkas, 22 August 1955), police played no role in the arrests. According to the Masjumi economist Jusuf Wibisono, the reason for the lack of police participation was because the force was highly politicized (Tangkas, 17 October 1955) whereas the military was relatively free of political bias. As was feared by many within the PNI camp, most of those under arrest or house arrest were politician connected with Ali Sastroamidjojo.

Burhanuddin's anti-corruption law was certainly controversial. NU, PNI and State Prosecutors and the Police were cautious because it provided the Prime Minister with the power to incarcerate opposition. Burhanuddin's anti-corruption effort was thus potentially unlawful. Soekarno wanted the bill to be discussed by a Parliamentary Consensus Committee before signing it. The cabinet relented and sent the anti-corruption draft to the Committee on 8 November. By the 29 November, the anti-corruption law was still in limbo as NU and PSII proposed non-essential amendments to the law. The law was not passed by Parliament before the end of the Burhanuddin Cabinet.

The third and last attempt at a civilian proclamation of anti-corruption, before the declaration of the anti-corruption regulation by the head of the military, General Nasution, on 9 April 1957 (Duta Masyarakat, 10 April 1957). The main difference between the approaches taken by the three law proposals were the types of courts used. Abbas's plan called for the creation of a Corruption Court in each High Court in the country. A new court would also have to be created to process corruption cases conducted by the army. The District Attorney's concept would pull together the corruption cases into one Special Criminal Court which would process both civil and military cases. Under Cabinet Ali Sastroamidjojo II, Ministry of Justice Moeljatno proposed a law that put corruption cases in ordinary courts in accordance with the rules of the criminal court. More importantly and in light of the Burhanuddin's extra-legal approach to anti-corruption, the proposal would have placed the Supreme Court and the police under the Ministry and was denounced by state prosecutors and the police as further politicizing the justice system (Lev, 2013: 63-65). Moeljato proposed the creation of a Corruption Eradication Coordination Body or the AntiCorruption Coordination Body and the Property Investigation Body both of which would be under the Ministry of Justice and would be composed of state attorneys, civilian and military officials and private individuals (Duta Masyarakat, 11 April 1957).

The Burhanuddin's corruption eradication effort failed. 16 people accused included four ministers, two police officers, seven officials and three private individuals. Former Minister of Economic Affairs Isqak Tjokrohadisurjo left for the Netherlands and returned only after the second Ali Cabinet was installed. Mr. Djody Gondokusumo, which had been 
processed through the CPM and subsequently brought to court, received a rather light sentence of one year, which was made lighter when the President pardoned six months off his term (Duta Masyarakat, 9 September 1956).

\section{Army Anti-Corruption}

It would require the end of the Second Ali Sastroamidjojo Cabinet and the start of Martial Law on 14 May 1957 for the military to have the legal justification to conduct a series of anti-corruption raids. On 28 March 1957 the commander of the CPM called on a number of high profile names for corruption investigation, which included Dr. A.K. Gani, Mr. Iskaq Tjokroadisurjo, Dr. Ong Eng Die, ${ }^{4}$ Mr. Kasman Singodimedjo, Mr. Tan Po Goan, Dr. Sumitro Djojohadikusumo, ${ }^{5} \mathrm{Mr}$. Sjafruddin Prawiranegara, Mr. Jusuf Wibisono ${ }^{6}$ (Wibisono, 1980: 222), Dr. Lie Kiat Teng, Dr. Saroso, Arudji Kartanegara, Djamaluddin Malik and others (Keng Po, 28 March 1957). Of the total, 37 people were under investigations. Unlike the Burhanuddin raid, the military raid focused on lawmakers from both the social democrats of the PSI and Masjumi and the nationalists of the PNI.

The military also conducted raids in banks and violated deposits of Chinese, Dutch and Indian minorities. Foreign currencies, unlicensed gold bars, firearms and ammunition, and documents were confiscated. Managers of Dutch and British banks were taken into custody. ${ }^{7}$ There was a degree

4) Ong Eng Die founded the Bank Umum Nasional along with several friends with an initial capital of 2,5 million rupiahs and paid up capital of 500 thousand rupiah. He obtained three priority shares and twenty regular shares from the company and during his position as finance minister, he gave BUN a 20 million rupiah credit, at a time when he was still the director and largest shareholder of the company. Three months after the credit approval, Ong Eng Die gave a treasury guaranteed Bank of Indonesia credit facility of 10 million rupiahs.

5) Sumitro Djojohadikusumo was accused to have obtained two-and-a-half million rupiahs from businessman Khouw Kim Eng which was to be used for the Partai Sosialis Indonesia. He was officially detained by the CPM, which issued a warrant for his arrest on 18 May because he had fled first to Tokyo on a financial experts conference. He showed up again at the national limelight through his open letter on 26 May sent from Central Sumatera where he had sought refuge and joined the PRRI rebellion. He showed up again at the national limelight through his open letter on 26 May sent from Central Sumatera where he had sought refuge and joined the PRRI rebellion. He reiterated that the money from Khouw Kim Eng was a political contribution to strengthen the campaign of the PSI during the 1955 election and that he was not holding any executive position, working at the time as the head of the action committee organization of the party.

6) Jusuf Wibisono was questioned to his credit facility policy in which the government disbursed some 325 million rupiah credit to companies thought to be close to the ruling coalition. The credit was composed of 250 million to the industries, 50 million to tobacco farmers and 25 million to import papers. Wibisono argued that the credit formed part of the 1956 national budget plan and was thus legal. He denied that the credits were all given to businessman with the connection to the PNI, NU, and Masyumi coalition party, even though he admitted that those businessmen who obtained credit were first screened through parties.

7) Australia National Archive, army intervention on civilian affairs. A1838. 
of xenophobia in the corruption eradication effort. To an extent, the idea was that much of the problems associated with the failure of democracy had a foreign element to it. This was the year in which, after one year of the end of diplomacy with the Netherlands, the Dutch/Eurasian community of Indonesia was forcibly 'repatriated' to the Netherlands. Practically all of the corruption cases conducted by the military involved either a Chinese businessman or were of Dutch/Chinese extraction. Dr. A.K. Gani obtained money from Khouw Kim Eng, a businessman, and owner of the NV. Indonesian Rubber Industries, among others. Dr. Lie Kiat Teng and Ong Eng Die were Chinese cabinet ministers. The case of Sardju Ismunandar ${ }^{8}$ (van der Kroef, 1960: 49-63) in the trading office of the Ministry of Economic Affairs were linked with a series of posts in other economic institutions of the government who were staffed by the few amounts of Dutch/Indo, including Sjarif Tjahja who was an Indonesianized Dutch with the name of van Straalen and J.A.A. van Dulken of the Foreign Exchange Bureau (Keng Po, 4 May 1957). The military was also to issue regulations to monitor and restrict the position of foreign experts working in Indonesia in 1957 (Keng Po, 6 June 1957). Corruption cases that were outside the bound of these largely publicized campaigns were less xenophobic in nature. This may also explain the focus on institutions that dealt with foreign relations such as the Bureau of Foreign Relations, the Foreign Exchange Bureau and the Office of Import Affairs. A look into the corruption case of the Masjumi Parliamentarian, Hadji Tjikwan points to the nature of corruption during the Parliamentary period.

\section{PT. Veemcombinatie Tandjong Priok Indonesia ${ }^{9}$}

The VTPI was a 'nationalized'Dutch company Fa. Veembombinatie Tandjong Priok (VTP), which was a group comprised of four storage companies, the NV Java Veem, NV Indische Veem, NV Verenigde Prauwenveem and NV Batavia Veem. These storage companies were owned by various large Indies trading houses and banks. Java Veem was co-owned by Tiedeman \& van Kerchem and Geo \& Wehry, Indische Veem was co-owned by Factorij (NHM) and Nationale Handelsband, Verenigde Prauwenveem was co-owned by VPV and Gutwirth trading company and Batavia Veem was owned by Kooy and Coster van Voorhout and Escompto bank. The value of VTP was estimated to be around 25.611.500 rupiahs.

In 1954, the parliament passed the law no. 61, which stipulated that all port facilities should be in Indonesian hands and that a transfer of ownership should occur (Linblad, 1963: 121-122). According to the

8) He would become the acting director of Bappit, which managed around 170 Dutch nationalized companies in the field of industry.

9) ANRI, Jakarta, BAPEKAN inv. nr. 808. 
manager of the VTP, H.J van Leeuwen, since 1956 the company's ability to function was gravely hampered because its operation permit was not issued. As a result, the company shut down. 3 August 1956, the company was sold to a prospective buyer named Kyai Hadji Tjikwan, a parliamentary member from the Masjumi Party who was head of the Economic Section of Parliament (Noer, 1987). With two partners, Mohammad Junan Nasution, another Masjumi member, and Khouw Bian Tjeng, a Chinese-Indonesian businessman. The VTPI was created on 20 August 1956 and obtained storage permit on 30 August, despite having no physical asset for storage. The cost of the purchase was 5 million rupiahs and 2 million guilders. The 5 million rupiahs were to be paid in ten installments of 500 thousand rupiahs, which was from an estimated 50\% of annual income to be paid no later than 1960 . The 2 million guilders were to be paid in 10 installments of 200 thousand guilders annually to be paid no later than 1959 .

On July 1960, the military ruler of Tandjong Priok (Peperdais) undertook an operation to fix the inefficiencies of the port. The case against VTPI had started since the military corruption bust of 1957. They found anomalies with the case. According to the Foreign Exchange Bureau (LAAPLN), there had been no request for foreign exchange transfer in guilders from VTPI to VTP between 1956 and 1959. In 1957, Khouw Bian Tjeng sold his share of the company to Hadji Tjikwan and left the country in February 1957 to Hong Kong and did not return. The transaction happened during the Burhanuddin Cabinet, a period in which Masjumi and PSI were in control of the government. It was cited by the interview with van Leeuwen that the reason why the company was sold was that Hadji Tjikwan had political capital, despite the fact that there was no assurance of the payment of the purchase. The brevity in which the company obtained a permit was noted as odd. The prosecutor cited that Masjumi party has been banned since 1960 and, thus, the purchase represented a security risk for the country. He noted the possibility of Khouw Bian Tjeng to be agents of Kuomintang because rumors had it that he had left Hong Kong to Taiwan. With no transfer of money from the VTPI to the VTP, the prosecutor concluded that there was either an illegal transfer or that the company never changed hands. They reached the conclusion that it was illegal to transfer, which was a violation of the law.

\section{Corruption during the 1950 s}

Corruption during the period followed the lines of power emanating from Parliament. It was often in the form of outright asset transfer or through political patronage of key economic institutions, especially economic ministries, and the banks. Anti-corruption efforts were half-hearted and reflected the fragmented nature of the political class. Yet because 
it was fragmented, anti-corruption efforts do get pushed through. The Burhanuddin sting singled out Ali Sastroamidjojo Cabinet ministers, while the army sting caught people from both sides of the fence. Asset transfer itself was not problematic and in fact was decreed into law. Indonesianization was thus part of a reorganization of rent-seeking within a system that was suboptimal. The competitive nature of the system allowed for some action to be conducted and some parliament members and businessmen did go to jail, but with light terms. Whether the system was on its way to finding a more optimal level is doubtful. Yet economic growth did occur despite the instability of government. It may have been on its way to become a system of stable but mediocre growth, as prevalent in many underdeveloped nations. Yet, before that happened, the military undercut the system and ushered in the Guided Democracy.

\section{The Guided Democracy Transformation}

The Guided Democracy resulted in a transformation of the economy within the vision of Soekarno's Revolutionary State. Although anti-corruption heralded the rise of the Guided Democracy, with the army sting operation under General Abdul Haris Nasution, it became less of an issue during the Guided Democracy. Instead, the idea was on 'social control' engineered through a revamp of the economy through a participatory approach. This was seen in the creation of the new organization that would allow greater participation, which often times meant more Communist involvement. The idea of social control was that as more people participated in making the decision, it would create greater acceptance of the decision and lessen the chance of people defaulting on it. A series of the organization was created in order to fulfill this participatory character of the state: the National Front, the National Planning Council (Depernas), the Company Boards (Dewan Perusahaan) and so forth.

Yet, despite this participatory push, there was another side to the equation of the Soekarno presidency. Centralization occurred after 1962, with the failure of the Depernas and its Eight Year Plan, yet it was also quite clear that the road to a strong state controlled from the President's Office occurred much earlier. The changes to the Central Bank, as will be seen below, represented this push for greater control of the monetary system under the President's command. Major restructuring of the governmentowned sector, which had ballooned as a result of the take-over of Dutchowned companies were met with administrative problems. By 1966, official statistics noted that there were 2.5 million people employed in government owned-companies, outside daily laborers. There were 217 state companies, 50 companies owned by the state, 300 provincial level companies and over a 
thousand district level companies. ${ }^{10}$

Control was also exhibited by the ending of many foreign relations, especially foreign investment. Indonesia had an ambivalent attitude toward investment. Since the early 1950s, the leadership often points the importance of foreign investment for the development of the country, yet the foreign investment law which was drafted by parliament in 1953 was only passed in 1958. In the field of oil exploration, there had effectively been a moratorium since 1939 and only in 1960 did the Government Issue a production sharing law on oil and petroleum (Oei, 1969: 33-66). Dutch-owned companies were nationalized in 1957 and in 1963-1965, the remaining foreign investments, some 90 companies from the US, Britain, Belgium, Malaysia, and others, were nationalized. In 1965, FDI was prohibited (Redfern, 2010: 2-3). Instead, a new form of 'production sharing' method was introduced, initially introduced by Japanese companies in the early 1960s. This model, as Joyce Gibson has analyzed, failed in attracting the needed foreign investments. Only four contracts were signed with Western nations amounting to 15 million dollars, while more contracts were signed with Japanese companies worth 44 million dollars. In total, there were only 72 million dollars total commitments and 12 million dollars had been extended by 1966 (Gibson, 1955: 84-86). The Eight Year Overall Development Plan wanted foreign investment for Indonesia's low hanging fruit sectors in the form of production sharing, yet, this model has failed in attracting any large-scale investment ${ }^{11}$ (Kano, 2008: 230-232).

Two cases below showed different forms of rent-seeking within the Guided Democracy. On the one hand was the blatant and highly unsustainable restructuring of the Central Banking system and on the other hand was an effort to create rent through a production sharing contract with a foreign company.

\section{The Case of Jusuf Muda Dalam ${ }^{12}$}

Jusuf Muda Dalam was the Minister of Central Bank Affairs since September 1963. Born in Sigli, Aceh, he had finished high school in Java. Afterwards, he attended the Rotterdam School of Economics (Economische Hogeschool) since 1936. Before completing his degree, the Netherlands had capitulated to Germany. In 1947, he had joined the Ministry of Defence in Indonesia. In the early 1950s, he became parliament member as representative of the

10) ANRI, Jakarta, Menneg EKUIN inv.nr. 4914. Dewan Perusahaan.

11) Even in the field of oil and gas, where three companies obtained production sharing contracts with three of Indonesia's state-owned oil companies found the political situation to be impossible, with Shell terminating its Indonesian operation by the end of 1965 and Stanvac reducing their presence, selling its main oil refinery to the Indonesian government.

12) The case of Jusuf Muda Dalam was published by the New Order regime as part of its effort to discredit the Soekarno regime. Proses Peradilan Jusuf Muda Dalam ex Menteri Urusan Bank Sentral "Kabinet 100 Menteri": Gema dari ruang sidang pengadilan subversi Jakarta. 
Communist Party. He left the PKI and joined the PNI in the mid-1950s. In 1956, Margono Djojohadikusumo offered him a job at the BNI. Since 1959, he had been appointed as a Director in the Central Bank. As a Soekarnoist and a member of the PNI, he was predisposed to the goodwill of the president.

When taking over the Ministry of Central Bank Affairs, the Central Bank had changed beyond significantly from its former 1950s self. Formerly known as de Javasche Bank, Bank Indonesia was an independent bank, lender of last resort and regulator of the monetary condition of the country. Its annual report gave an accurate picture of the country's worsening monetary condition, high inflation, and constant deficit. In 1957, the Central Bank was restructured. It lost its independence and stopped issuing bank statistics since 1959, keeping the public in the dark concerning the monetary condition of the country (Prawiro, 1998: 3-4). Losing oversight of the monetary system, Bank Indonesia acted as any other commercial bank. The Bank used to have a monetary board whose main purpose was to craft a monetary plan. Since 1962, the monetary board was dismissed and the Bank effectively became an extension of the Presidential Office. Its main purpose was to provide the necessary funds for Indonesia's Eight-Year Development Plan and the President's mandated projects.

In 1965, a series of reforms conducted by Muda Dalam exacerbated the condition. He restructured all state-owned banks within the Central Bank. Bank Indonesia was renamed as BNI Unit 1 and all other stateowned banks as Unit 2, Unit 3 and so forth. The restructuring of the bank eliminated competition. Private Banks were tiny in comparison and the last foreign banks were nationalized in $1964^{13}$ (Laporan Bank Indonesia 1960-1965: 67). Since 1961, Indonesia had borrowed heavily from various countries and the IMF (which provided 20 million dollars annually in 19621964). By 1966, its debt would accrue to 2.5 billion dollars. With worsening export number since the Konfrontasi in 1963 closed Malaysian/Singaporean market, the ability of Indonesia to service its debts began to falter. In order to maintain imports, the Central Bank issued a deference payment credit scheme. The deference credit provided assurance for foreign credit to be paid within one or two years, essentially a credit for imports. Indonesia had started rescheduling its debts by 1963 and 1964 because it did not have enough foreign credits to service its debts. Since 1964, countries like the Soviet Union (which had provided up to a billion dollars in credit) ${ }^{14}$ and Japan became weary of the possibility of a default. In late 1965, Japan halted Indonesian imports.

Instead of belt-tightening and reduction of the so-called Revolutionary

13) These were OCBC, Bank of China, HSBC and the Chartered Bank.

14) The Soviet Union, for instance, took 15 million dollars in the form of a deferred payment credit in 1964 and 1965. 
Projects, Muda Dalam channeled a part of the deference payment credit for the Revolutionary Fund. For each dollar credit given, 250 rupiahs were put into the Revolutionary Fund. The credit deference scheme was detrimental especially because it provided import credits outside of the Import Plan, thus allowing for non-essential imports. The deference payment credit amounted to 270 million dollars and the Revolutionary Fund was estimated to be around 50 million dollars. With no regulatory body to oversee these credit schemes, it was ripe for corruption on a grand scale. The credit was given after consent from the Minister Muda Dalam, thus naming him a 'monetary czar' of the country. The Revolutionary Fund was disbursed on companies with a connection to Jusuf Muda Dalam or Soekarno himself.

This includes companies like PT Bluntas, which had obtained government contracts to build the Banteng Hotel, a housing estate in Pulo Mas, Jakarta and a ship-building venture with Dutch companies. PT Bluntas obtained 21 billion rupiahs from the Revolutionary Fund. Muda Dalam was Commissioner for the company. According to prosecutors, 11 billion rupiahs were paid for the Farmer's Congress (Mubes Tani) and the IPPI, both PKI affiliated organizations. Another important company to receive the Fund was PT Karkam, owned by Acehnese Markam, a former military man who had obtained government credit in 1957 through the President. PT Karkam was appointed as a Tool of the Revolution Company in March 1965. According to Markam, he met with the President weekly to discuss company finance. The company basically did the biding of Soekarno's projects. Obtaining 15 million dollars worth of deferred credit, the company invested in textiles and various ventures. The Revolutionary Fund was also meant to fund major projects such as the National Monument (Monas). The NU obtained 225 million rupiahs in the donor, while the PNI received 200 million. 75 million rupiahs were also given to the Bung Karno University.

Along with important members of Soekarno's Cabinet, Muda Dalam was put on trial in a spectacularly public manner. His trials were published in newspapers and aired on the radio. It was called 'the greatest crime of the century' and the airing of his sexual life with various celebrities, including the famous singer Titiek Puspa, was to put to stamp his immoral character. The trials were held at the Bappenas building and, whether unintentional, had a poetic ring as a symbol of the new, technocratic order punishing to old, weakened political class. While Jusuf Muda Dalam was guilty of indulging in what many would probably have guessed to be a terminally ill system, there was very little effort to pin it on Soekarno. Yet, the trial also functioned to symbolically put the President on trial. Opening up Muda Dalam's sins showed it to be inextricably linked with Soekarno's. Putting in parade Muda Dalam's various love affairs was also a not so subtle hint at Soekarno's lecherous history. It was thus perhaps not a coincident that of 
the twenty-something witness of the trial, the last to testify was Markam of PT Karkam as well as Mr. of PT. Aslam, two well known 'palace millionaires' (Crouch, 1975-76: 523). The trial also showcased the bankrupt system of the Guided Democracy. How the system had no possible outcome other than the eventual default of the Indonesian economy.

\section{PT. Pembangunan Industri Tani Atjeh ${ }^{15}$}

One case in point is the production sharing contract signed between Colonel Sjamaun Gaharu as representative of a new company called the PT Pembangunan Industri Tani Atjeh (PITA) and the Bulgarian company, Technoexport, from Sofia. The contract was for the production of Citronella and Patchouli oils. It was signed on 11 May 1965. It stipulated that Technoexport of Sofia was to plan and create a Citronella plant in Blangrakal, Aceh, near Takengon. Technoexport would send machinery for the plant and technical experts both for the planning of the site, the design of the plant, the overview of its construction and technical experts to run the initial machinery. It would also train two Indonesian in Bulgaria on the technical aspects of the plant and if need be, provide a technician for an extended period of time once the plant was finished. Technoexport would provide credit to the tune of over 775 thousand dollars in the form of machinery and expertise. This would be paid by allowing the company to sell 50\% of the Citronella and Patchouli oil the plant produced for a period of five years in the European market. In the meantime, PT PITA would provide for the land, workers and raw materials needed to run the plant. PT PITA itself was created specifically for the venture and notarized in early 1965. The President Director was Sjamaun Gaharu, a veteran of the revolution. The Commissioner President of the company was a politician and former minister Iskaq Tjokrohadisurjo.

The government's effort to increase export of Citronella oil was part of the drive within Soekarno's berdikari slogan and especially as a result of the drop in export when Konfrontasi with Malaysia and Singapore closed the Indonesian market for the oil. The Ministry of People's Industry had wanted to set up Indonesia's 'first modern distillery' in Tawangmangu, Central Java. A contract had been signed between Technoexport and PNPR Kimia Yasa. As Joyce Gibson had written, Kimia Yasa had already expended a significant amount of investment in pushing forth the project ${ }^{16}$ (Gibson). There is little evidence that the project between PITA and Technoexport came to a successful conclusion, it probably had been disrupted by the

15) The PITA case can be read in Contract for Cooperation on the basis of Production Sharing between PT PITA KEUMALA and Technoexport for the establishment of one essential oil extraction plant in Blangrakal, Aceh, Indonesia.

16) http://www.nber.org/papers/w12795, December 2006. 
coup. Yet it represented a model of private to private cooperation. Sjamaun Gaharu had requested to the Ministry that the plant is relocated to Aceh and that it be privatized. He was able to get a concession (hak guna usaha) of state lands managed by the Ministry of Forestry in the area near to Takengon and Bireun district of Aceh. PT Pembangunan Industri Tani Atjeh obtained an initial capital of 5 million rupiahs and planned to spend over 60 million rupiahs for land, 58 million rupiahs for buildings, 92 million rupiahs for transportation equipment, 376 million rupiahs for offices and housing and a grand total of 645 million rupiahs. It was not clear where the credit was for such expenditure.

Gaharu himself was a typical ‘businessmen' of the Guided Democracy. Born in Pidie, Aceh in 1913, he had initially attended school for the agricultural teacher (Opleiding voor Landbouwonderwijzer) in Bogor in 1939-1940. During the Japanese occupation, Gaharu joined the military training in the Giyugun and became Giyugun Tjui (first lieutenant). Since independence, he was active in organizing the Angkatan Pemuda Indonesia which became the core for the TNI in Aceh. In October 1945, he was appointed as Commander of Fourth Division as a Colonel. In 1946, he was transferred to as Head of Staff of the South Sumatra Sub-Commandment. In April 1947, he became Commander of the Second Regiment of the Tentara dan Territori (TT) Sumatera overseeing Lampung and South Palembang. During the Second Clash with Dutch forces, South Sumatra was made into a Special Military District, he was appointed as Vice Governor under Military Governor A.K. Gani, overseeing the Lampung and South Palembang districts. In April 1950, he became Commander of the Sub-Territory of the TT Kalimantan.

Since the start of martial law on 14 March 1947, Gaharu was appointed as the Military Head of Aceh. On 15 August 1959, he was appointed as a member of the Dewan Pertimbangan Agung. In 1960, he joined the C Course of Seskoad in Bandung and obtained a General Staff Qualified certificate. On 22 August 1960, he was appointed as head of the curatorial board of the Islamic Law Faculty in Kutaradja, Aceh. On 6 January 1961, he was appointed as Ministerial Aid to the Minister of National Security as part of the Karya appointment, in which military functionaries were appointed to a civilian post. On 1 January 1964, he was given the right to be relieved of military duties and work in the civilian field until his retirement on 1 January 1966. He was an almost prototypical example of the new army managerial class and their societal relationship that arose during the period.

PT PITA was created as a company in which veterans of the revolution could play a part in society, as was expressed by Gaharu himself. As part of the military elite, he had no problem obtaining both concessions from the Ministry of People's Industry to relocate the government's project from Java to Aceh and obtain the licenses necessary to use state lands for the plantation. 
Differing from Hadji Tjikwan and PT VTPI, PT PITA was bringing in new expertise and capital into an area that had little value, instead of an outright asset transfer had occurred. There is no evidence that the deal between PITA and Technoexport followed through, yet this is a model of asset creation in which local players obtain rent purely through their relationship with the state. While it was not a blatant theft of money as was the case of Jusuf Muda Dalam and the various businessmen associated with him or the President, this signals the diverse ways in which rent-seeking is obtained through regime changes.

\section{Conclusion}

In both cases of Parliamentary Democracy and Guided Democracy, corruption was a major issue that was used by new elite entrants to discredit the old system. The rise of the Guided Democracy was started as much by the anti-corruption effort of the army, while the rise of the New Order was predicated on the corrupt nature of the Guided Democracy. The parading of Jusuf Muda Dalam as lacking both administrative and moral compunction was to cement the rise of a new, more efficient and, hence, less corrupt New Order. This did not last long. Mackie's article on the anti-corruption effort of the New Order was written in 1970. The question here is: how does regime change create rent and how can the system be stabilized at a suboptimal level? ${ }^{17}$ How does the New Order get away with corruption, while previous regimes succumb? How is social or political order sustained while creating rent for its beneficiaries?

Such questions have to be answered historically and contextually within each giving society. Regime change represents opportunities for rent-seeking, yet creating open access societies, i.e. democratic ones, were fraught with creative destructive tendencies of growth. ${ }^{18}$ The instability of the parliamentary period may represent a creative destructive period in which new entrants into the system stake claim to rents through the formation of new relationships forged through positions within the state. Thus, many economic policymakers and their access to state funds or legislation allowed the rise of cooperation with businessmen. This vying for asset control may have contributed to the instability of the system, allowing everyone the chance to procure a limited term rent. The appearance of new entrants to the system, in this case, the army, made it unviable because the suboptimality of the system makes it prone to complete breakdown. Instead

17) According to Crouch, the New Order would eventually succumb to its destructive patrimonialism. Yet, it had quite a long life.

18) More on ideas of open access societies see Douglass North, John J. Wallis, and Barry R. Weingast, "A conceptual framework for interpreting recorded human history", http://www.nber.org/papers/w12795, December 2006. 
of sharing the spoils, as it were, it was better for the army to revamp it all together and obtain greater rent than anyone else out of it.

The presence of foreign aliens seemed to be an important part of the system. They not only represent a source of asset transfer, but also a source for asset creation. One can negotiate with Dutch owners for asset transfers that were enforced by the state as had occurred with KH Tjikwan and the VTPI or work together with, often times Chinese-Indonesian, businessmen and create assets through policies of state actors; for instance with the case of Ong Eng Die and the built up of Bank Umum Negara. Chinese as 'foreign aliens' also work in regard to asset creation and may perhaps be considered to be rent on service, in this regard the service of running businesses and, vice versa, the Indonesian power holder provides access to the state and its various forms of benefit. Foreign aliens also function as a deterrent in the discourse. Thus, the discussion surrounding corruption oftentimes alludes to the possibility of alien interference that endangers national interests. Because of its 'imaginary' character (there is no need to prove its correctness. Khouw Bian Tjeng may be a Kuomintang agent or that the VTPI may be a front for Dutch business to continue operating in Indonesia), foreign alien discourse is used to negotiate transfers of rent.

The replacement of an independent Central Bank to create a rentseeking structure that funneled money into personal projects and pockets were beneficial but extremely suboptimal. Jusuf Muda Dalam became quite rich and was able to hand out houses and cars to his many wives and mistresses. Other beneficiaries include Markam of PT Karkam and Abdulrachman Aslam of PT Aslam, two so-called 'palace billionaires' and others including Zahirsjah, the president director of PT Bluntas, T.A. Hamid Azwar, president director of PT Trisatria (in which Muda Dalam was chairman of the board), Djohan Ang director of NV Simurung and others. Zahirsjah, Azwar, and Karkam were all Acehnese. Again foreign relations were used to obtain money, this time from the Credit Deferred Payment Scheme. The 'foreign aliens' were in the form of countries and banks who were willing to give deferred credits to Indonesia in the hope that it would not default on its loans. This was obviously highly suboptimal and unsustainable, but in fact, Muda Dalam in his deposition said that countries weren't people and that the outside world was always ready to reschedule and renegotiate debts and its terms.

One can speculate that perhaps the corruption of the Indonesian elite during the Old Order was to recreate rent towards foreign aliens, whether they are foreign companies in Indonesia or trading relationship. Rent seeking can be particularly destructive as the case of Jusuf Muda Dalam and the Central Bank, yet it could also be constructive as with Sjamaun Gaharu and the Technoexport Company of Bulgaria. Thus, rent-seeking 
represented various differing strategies. It requires a more comprehensive reading of contextualized cases in order to deduce motivations and the institutional and organizational environment that allowed the rise of a corrupt Indonesian state. This is a role that historians can play a feasible part.

\section{References}

\section{Unpublish Archives}

ANRI, Jakarta, BAPEKAN inv. nr. 808.

ANRI, Jakarta, Menneg EKUIN inv.nr. 4914. Dewan Perusahaan.

Australia National Archive, army intervention in civilian affairs. A1838.

ARA, 2.10.14.3285, Algemene Secretarie, Letter from Lieutenant-Colonel P. Kapteijn to the Luitenant Governor-General, 22 March 1948.

Keterangan pemerintah atas program kabinet Ali Sastroamidjojo. Kementerian Penerangan: Jakarta, 1953.

Proses Peradilan JusufMuda Dalam ex Menteri Urusan Bank Sentral "Kabinet 100 Menteri": Gema dari ruang sidang pengadilan subversi Jakarta. Jakarta: Kedjaksaan Agung Bidang Khusus, 1967.

These were OCBC, Bank of China, HSBC and the Chartered Bank. Laporan Bank Indonesia. 1960-1965, p. 67.

The contract for Cooperation on the basis of Production Sharing between PT PITA KEUMALA and Technoexport for the establishment of one essential oil extraction plant in Blangrakal, Aceh, Indonesia. Jakarta: Tan, n.a.

\section{Books}

Feith, Herbert (2009). The Wilopo Cabinet 1952-1953. A turning point in postrevolutionary Indonesia. Singapore: Equinox.

Harahap, Burhanuddin (1956). Keterangan dan jawaban pemerintah tentang program kabinet. Kementerian Penerangan: Jakarta.

Kano, Hiroyoshi (2008). Indonesian exports, peasant agriculture, and the world economy. 1850-2000. Economic structures of a Southeast Asian state. Singapore: NUS Press.

Lev, Daniel (2013). Hukum dan Politik di Indonesia. Kesinambungan dan Perubatan. Jakarta: LP3ES.

Lindblad, Thomas (2008). Bridges to new business: the economic decolonization of Indonesia. Leiden: KITLV.

Noer, Deliar (1987). Partai Islam di Pentas Nasional. Jakarta: Pustaka Utama Grafiti.

Noermattias (peny.) (1973). Latihan pembinaan pimpinan training within industry (TWI) dan management untuk pembangunan. Ichtiar Baru: n.a.

Prawiro, Radius (1998). Indonesia's struggle for economic development. Pragmatism in action. Oxford: Oxford University Press.

Robison, Richard (2009). Indonesia: the rise of capital. Singapore: Equinox.

Sutomo (1952). Koordinasi dalam Republik Indonesia. Malang: Balapan.

Wibisono, Jusuf (1980). Karang di tengah gelombang. Gunung Agung: Jakarta.

Articles

Crouch, Harold (1979). 'Patrimonialism and military rule', World Politics 31, 4: 571587. 
(1975-76). 'Generals and Business in Indonesia', Pacific Affairs 48, 4: 523.

Gibson, Joyce (1955). 'Production sharing part II', Bulletin of Indonesian Economic Studies 2, 4: 84-86.

"Production sharing part II"."A conceptual framework for interpreting recorded human history", http://www.nber.org/papers/w12795 (December 2006).

Hodgson, Geoffrey M. \& Shuxia Jiang (2007). 'The economics of corruption and corruption of economics: an institutionalist perspectives', Journal of Economic Issues 31, 4: 1043-1061.

Kroef, Justus van der (1960). 'Indonesia’s economic dilemma', Far Eastern Survey 29, 4: 49-63.

Mackie, Jamie (1970). 'The Commission of Four reports on corruption', Bulletin of Indonesian Economic Studies 6, 3: 87-101.

(2010). 'Patrimonialism: the New Order and beyond', in: Edward Aspinall and Greg Fealy (eds). Soeharto's New Order and its legacy. Canberra: ANU Press.

Oei, Hong Lan (1969). 'Implication for Indonesia's New Foreign Investment policy for economic development', Indonesia 7.

Palmier, Leslie (1982). 'The control of corruption in the developing world', India International Centre Quarterly 9, 1:3-12.

(2006). 'Indonesia: corruption, ethnicity and the 'pax-Americana', Asian Affairs 32/2: 147-160.

Wie, Thee Kian (2009). "Indonesianization. Economic aspects of decolonization in Indonesia in the 1950s", in: Thomas Lindblad and Peter Post (eds), Indonesian economic decolonization in regional and international perspectives. Leiden: KITLV.

\section{Dissertation}

William Redfern (2010). Soekarno's Guided Democracy and the takeover of foreign companies in Indonesia in the 1960s (Dissertation, University of Michigan: America Serikat).

\section{Newspapers}

Duta Masyarakat, 9 September 1956.

Duta Masyarakat, 10 April 1957.

Duta Masyarakat, 11 April 1957.

Keng Po, 28 March 1957.

Keng Po, 4 May 1957.

Keng Po, 6 June 1957.

Tangkas, 17 July 1955.

Tangkas, 22 August 1955.

Tangkas, 6 September 1955.

Tangkas, 23 September 1955.

Tangkas, 1 October 1955.

Tangkas, 17 October 1955. 